ENTREPRENEURSHIP AND SUSTAINABILITY ISSUES

ISSN 2345-0282 (online) http://jssidoi.org/jesi/

2019 Volume 7 Number 2 (December)

http://doi.org/10.9770/jesi.2019.7.2(27)

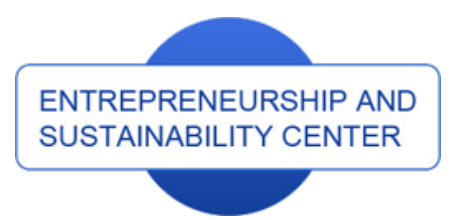

Publisher

http://jssidoi.org/esc/home

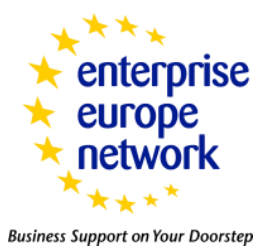

CASPA

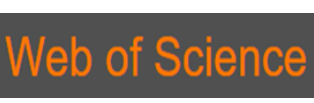

1) Clarivate

\title{
IMPLEMENTATION OF CONTROLLING TECHNOLOGIES AS A METHOD TO INCREASE SUSTAINABILITY OF THE ENTERPRISE ACTIVITIES*
}

\author{
Tatyana Khudyakova ${ }^{1}$, Andrey Shmidt ${ }^{2}$, Svetlana Shmidt ${ }^{3}$ \\ 1,2 South Ural State University, Department of Applied Economics, 76, Lenin av., Chelyabinsk, Russia \\ ${ }^{3}$ Saint-Petersburg State University, Department of Mathematics and Computer Science, Saint-Petersburg, Russia \\ E-mails: ${ }^{1}$ khudiakovata@susu.ru; ${ }^{2}$ shmidtav@susu.ru; ${ }^{3}$ lana0771711@gmail.com
}

Received 21 August 2019; accepted 18 October 2019; published 15 December 2019

\begin{abstract}
We are currently facing that business environment is not stable due to globalisation processes in economics, cyclical changes and other disturbing factors. Hence, it is necessary to search such reserves that would improve efficiency of the business entity. The main objective of these reserves is to buffer negative impacts of external disturbances on financial and economic sustainability of enterprises. One of methods designed to improve the enterprise efficiency involves application of controlling technologies. In the present article the author examines results of statistical analysis of economic performance of more than 70 Russian and foreign enterprises. The author also analyses economic performance according to the author's integral indicator that shows effectiveness of primary implementation of the controlling system. On the ground of this analysis, the author determines the mean level of increase in efficiency of the enterprise's activity due to introduction of the controlling system. The analysis proves that, on average, efficiency of the economic entity's operation increases by about $17 \%$.
\end{abstract}

Keywords: stability of the enterprise; economic sustainability; financial sustainability; controlling system; controlling technologies; risk; disturbing influences; effectiveness

Reference to this paper should be made as follows: Khudyakova, T., Shmidt, A., Shmidt, S. 2019. Implementation of controlling technologies as a method to increase sustainability of the enterprise activities. Entrepreneurship and Sustainability Issues 7(2): 1185-1196. http://doi.org/10.9770/jesi.2019.7.2(27)

JEL Classifications: G32, M40, Q01, O10, O21

\footnotetext{
* South Ural State University is grateful for financial support of the Ministry of Education and Science of the Russian Federation (grant No 26.9677.2017/BP). The work was supported by Act 211 Government of the Russian Federation, contract № 02.A03.21.0011.
} 


\section{ENTREPRENEURSHIP AND SUSTAINABILITY ISSUES}

ISSN 2345-0282 (online) http://jssidoi.org/jesi/

2019 Volume 7 Number 2 (December)

http://doi.org/10.9770/jesi.2019.7.2(27)

\section{Introduction}

Fluctuations of external environment cause economic recession, and in this context socio-economic space is quickly getting more and more diverse. External disturbances significantly affect the state of the industrial cluster, reducing its financial and economic stability. The controlling system is specially designed to neutralize the impact of such disturbances on activities of the economy‘s terminal segment, the enterprise.

However, today scientists and businesses do not pay sufficient attention to methodological issues in the field of developing and implementing controlling systems, which would serve as the basis for increasing sustainability of economic entities through preventive management aimed to reduce the negative impact of environmental disturbances, i.e. disturbances caused by operational environment (Ghosh et al. 2019). The controlling models that currently in use are mainly limited to functions of keeping accounts, controlling and planning. Most of existing models do not forecast what impact environmental uncertainty can have on indicators of financial and economic performance of the enterprise. This phenomenon can be attributed to the history of controlling systems in the Russian Federation - in fact, controlling systems were first mentioned in Russia only after perestroika. The first approaches to introduce strategic management at the economic entity emerged only at the turn of the $21 \mathrm{st}$ century. Since then, strategic management has been considered as dominating against the concept of accounting (Pelau and Rosca 2017). Thus, there are objective factors explaining why scientific literature presents practically no quantitative assessment of that influence the introduction of controlling systems has on financial and economic performance of the enterprise. Indeed, few researchers have attempted to quantify the impact of launching the controlling system on business performance, though most of contemporary scientific papers note positive aspects of controlling.

\section{Methodological approach}

To assess the impact of launching the controlling system on business performance, we need to take the following steps: analyse Russian and foreign experience in this field; process results of this the analysis by means of probabilistic and statistical methods (Zhuravlyov et al. 2018); develop integrated indicators that would allow us to come to generalized conclusions as to how introduction of the controlling system improves efficiency, both with regard to certain activities of the business entity and the enterprise as a whole (Khudyakova, Shmidt 2018).

In this context, our research shall comprise the following main stages:

$>$ To collect, summarise and analyse information related to effectiveness of controlling systems (Grynko et al. 2016; Parumasur and Govender 2013);

$>$ To calculate statistical indicators based on the data obtained from this analysis (Bertašius 2007);

$>$ To set and calculate integral indicators;

$>$ To make conclusions on the conducted research.

In order to compute the average value of the effect that implementation of the controlling system has on performance indicators of various activities of the enterprise (Shevchuk 2014), we find it possible to use a weighted average indicator:

$$
\overline{E_{i}}=\frac{\sum_{j=1}^{n}\left(E_{i j} * f_{i j}\right)}{\sum_{j=1}^{n} f_{i j}},
$$


where $\overline{E_{i}}$ is the weighted average value of increase in i-type efficiency due to launching the controlling system at the enterprise; $E_{i j}$ is the increase in i-type efficiency resulted from launching the controlling system at the $\mathrm{j}$ enterprise; $f_{i j}$ is repetition frequency of $\mathrm{j}$-event; $n$ is the amount (number) of data under analysis.

In addition, it seems necessary to determine the confidence interval for the general average, which would allow with a probability of at least 0.95 to declare that the average value of i-type efficiency increase due to launching the controlling system at the enterprise will not exceed the found interval in case of a gross sample:

$$
S_{i}=\frac{\sqrt{\sum_{j=1}^{n}\left(E_{i j}-\overline{E_{i}}\right)^{2} * f_{i j}}}{\sum_{j=1}^{n} f_{i j}-1}
$$

where $S_{i}$ is an estimate of the root-mean-square deviation of the increase in the $i$-type efficiency due to launching the controlling system at the enterprise.

Then the confidence interval for the average value of the increase in i-type efficiency due to launching the controlling system at the enterprise will be calculated with Formula (3):

$$
\left(\overline{E_{i}}-t_{\text {table }_{i}} * \frac{S_{i}}{\sqrt{n}}, \overline{E_{i}}+t_{\text {table }_{i}} * \frac{S_{i}}{\sqrt{n}}\right),
$$

where $t_{\text {table }_{i}}$ - is Student's t-criterion.

In order to come to a generalised assessment of the efficiency of launching the controlling system at the enterprise, we propose to use the integral indicator:

$$
E_{\text {int. }}=\sqrt[m]{\prod_{i=1}^{m} \overline{E_{i}}}
$$

where $m$ is the number of analysed types of indicators that show efficiency of launching the controlling system.

\section{Theoretical Framework and Literature Review}

Thus, we will analyse the increase of efficiency due to launching the controlling system at the enterprise by applying the above stated methods.

As we have already noted, there are currently no papers providing generalized information on how introduction of controlling influences the performance indicators of one economic entity that could be projected onto a group of homogeneous enterprises (Mousavifard et al. 2016). Therefore, we find it essential to make necessary calculations and draw conclusions applying the proposed set of methods. 
In their article "Controlling in Russia" founders of controlling in Russia Falco S., Russell K. and Levin L. claim that according to experts estimate, introduction of the controlling system at the enterprise "can result in achieving the growth of integrated performance indicators by 15-30\%" (Falco, Russell \& Levin 2015). Herewith, introduction of controlling at enterprises engaged in innovative development will increase their efficiency by about 50-75\% (Falco, Russell \& Levin 2015).

Syuzeva O.V. (Syuzeva 2010), Yunusova D.A. (Yunusova 2009), and Yusupova S.Ya. (Yusupova 2008), Golovanova N.B., Basyuk A.S., Taranova I.V., Kramarenko E.R., Goloshchapova L.V. (Golovanova et al. 2016) conducted a research based on official data of the Chamber of Commerce and Industry (The data of the chamber of Commerce of the Russian Federation 2006). Similar conclusions can be drawn based on Suhaimi, Nawawi and Salin's research (Suhaimi et al. 2016).

According to their research and the methodological approaches listed above, the effectiveness of made decisions calculated as the increment in profit to the cost increase significantly improved due to the implementation of the controlling system at industrial enterprises. Using the results of their research, we determined that the initial implementation of controlling in Russian enterprises contributed to the increase in the efficiency of decisionmaking from $11 \%$ to $18.9 \%$ (Table 1) and the increase in the productivity of managers from $9.6 \%$ to $16 \%$ (Table 1).

Table 1. Effectiveness of the primary implementing controlling at industrial enterprises (in the short-term)

\begin{tabular}{|c|c|c|c|}
\hline & Indicator & $\begin{array}{c}\text { Rate of increase in the } \\
\text { effectiveness of the decision } \\
\text { made, } \%\end{array}$ & $\begin{array}{c}\text { Growth rate of labor } \\
\text { productivity of } \\
\text { management personnel, } \%\end{array}$ \\
\hline \multirow{6}{*}{ 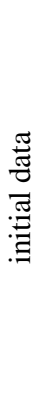 } & Sistema OJSC & 11.0 & 12.6 \\
\hline & Power Machines PJSC & 16.2 & 16.0 \\
\hline & PJSC Inter RAO & 15.0 & 14.3 \\
\hline & Bishkek Machine-Building Plant OJSC & 13.2 & 9.6 \\
\hline & Holding Company SUIholding LLC & 18.9 & 14.5 \\
\hline & Hals Development PJSC & 15.9 & 12.2 \\
\hline \multirow{5}{*}{ 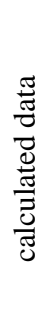 } & Variation range for the indicator value & $11.0-18.9$ & $9.6-16.0$ \\
\hline & The theoretical mean value & 15.03 & 13.2 \\
\hline & Mean square deviation & 2.47 & 2.04 \\
\hline & Variability index & $\begin{array}{c}16.45 \\
\text { (weak variation) }\end{array}$ & $\begin{array}{c}15.48 \\
\text { (weak variation) }\end{array}$ \\
\hline & Integrating efficiency indicator & \multicolumn{2}{|c|}{14.09} \\
\hline
\end{tabular}

Source: compiled by the authors based on

(The data of the Chamber of Commerce of the Russian Federation 2006, Syuzeva 2010, Yunusova 2009)

At the same time, the efficiency of decisions is understood as the ratio of the increase in the value of the surplus product as a result of the implementation of a specific management decision to the increase in costs caused by this management decision. In our case, these solutions are understood as actions aimed at the formation and implementation of the controlling system in industrial enterprises. The increase in the productivity of managerial 
personnel is understood as an increase in the indicator calculated as the ratio of the products produced to the number of managerial personnel.

Thus, the theoretical mean value for increase in efficiency of the made decision amounts to $15.03 \%$, while the theoretical mean value for increase in the labour productivity of managerial personnel amounts to $13.2 \%$ (Table 1).

The calculations presented in Table 1 bring us to conclusion that the theoretical mean value of increase in the efficiency of the decision made and labour productivity in the given sample are almost identical. Herewith, the calculated coefficients of variation are not significant $(<30 \%)$, thus, the input data for analysis are considered homogeneous, which allows us to conclude that the calculations are valid. The integral indicator of increasing the efficiency of Russian enterprises due to implementation of the controlling system in the short term is $14.09 \%$ (Table 1).

In the long term the increase in the enterprises efficiency due to implementation of the controlling system is higher than in the short term (Table 2). For example, for Russian enterprises the integral indicator of efficiency of the controlling system in the short term varies within 14\% (Table 1), while in the long term it doubles and amounts to $32.46 \%$ (Table 2). At the same time, it is necessary to note that the quality of decisions is calculated as the ratio of the number of qualitatively executed decisions to the total number of management decisions taken at the enterprise.

Table 2. Efficiency of making long-term financial decisions based on primary controlling activities

\begin{tabular}{|c|c|c|c|}
\hline \multicolumn{2}{|r|}{ Company / Indicator } & $\begin{array}{c}\text { Growth rate of increase in } \\
\text { quality of decisions, } \%\end{array}$ & $\begin{array}{c}\text { Growth rate of management } \\
\text { effectiveness, } \%\end{array}$ \\
\hline \multirow{5}{*}{ 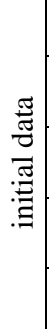 } & Luding LLC & 43.4 & 38.7 \\
\hline & SPI-RVVK OJSC & 41.1 & 36.9 \\
\hline & Locator LLC & 34.5 & 30.6 \\
\hline & Uniastrum Bank PJSC & 32.2 & 29.8 \\
\hline & Solid CJSC & 18.9 & 18.9 \\
\hline \multirow{5}{*}{ 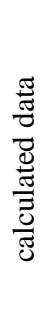 } & Variation range for the indicator value & $18.9-43.4$ & $18.9-38.7$ \\
\hline & The theoretical mean value & 34.02 & 30.98 \\
\hline & Mean square deviation & 8.61 & 6.96 \\
\hline & Variability index & $\begin{array}{c}25.3 \\
\text { (weak variation) }\end{array}$ & $\begin{array}{c}22.46 \\
\text { (weak variation) }\end{array}$ \\
\hline & Integrating efficiency indicator & \multicolumn{2}{|c|}{32.46} \\
\hline
\end{tabular}

Source: compiled by the authors based on (Syuzeva 2010, Yunusova 2009)

According to the research conducted by the international company PricewaterhouseCoopers (The Pricewaterhouse Cooper's bulletin, 2002), analysis of the impact of implementing the controlling system at foreign enterprises proved that the trends are similar to those in Russia (Table 3). 
Table 3. Efficiency of primary implementing the controlling system at foreign industrial enterprises

\begin{tabular}{|c|c|c|c|}
\hline \multicolumn{2}{|r|}{ Company / Indicator } & $\begin{array}{c}\text { Growth rate of management } \\
\text { effectiveness, } \%\end{array}$ & $\begin{array}{l}\text { Rate of increase in the efficiency } \\
\text { of the production process, } \%\end{array}$ \\
\hline \multirow{11}{*}{ 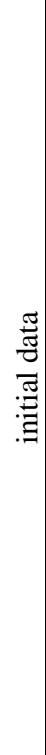 } & Sony & 25.0 & 18.4 \\
\hline & Samsung & 24.2 & 18.0 \\
\hline & LG & 18.7 & 25.9 \\
\hline & Akai & 11.8 & 8.4 \\
\hline & Kodak & 11.7 & 31.9 \\
\hline & Nokia & 10.2 & 25.3 \\
\hline & Mazda & 9.9 & 22.9 \\
\hline & Siemens & 9.3 & 21.5 \\
\hline & British Petroleum & 9.1 & 19.6 \\
\hline & Shell & 8.6 & 19.0 \\
\hline & AIG Brunswick Capital & 7.2 & 14.9 \\
\hline \multirow{6}{*}{ 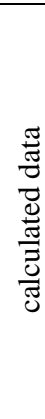 } & $\begin{array}{l}\text { Variation range for the indicator } \\
\text { value }\end{array}$ & $7.2-25.0$ & $8.4-31.9$ \\
\hline & The theoretical mean value & 13.25 & 20.53 \\
\hline & Mean square deviation & 6.06 & 6.17 \\
\hline & Variability index & $\begin{array}{c}45.74 \\
\text { (moderate variation) }\end{array}$ & $\begin{array}{c}28.65 \\
\text { (weak variation) } \\
\end{array}$ \\
\hline & Distribution type & normal distribution & normal distribution \\
\hline & Integrating efficiency indicator & \multicolumn{2}{|c|}{16.49} \\
\hline
\end{tabular}

Source: compiled by the authors based on (Yunusova 2009; The Pricewaterhouse Cooper's bulletin, 2002)

Checking samples for normality of the statistical law made it possible to conclude that the values of growth rates of management efficiency and the production process are normal. Herewith, the theoretical mean value for the increase in management efficiency at foreign industrial companies amounts to $13.25 \%$, while the increase in efficiency of the production process amounts to $20.53 \%$. At the same time, the calculated integral index is $16.49 \%$ (Table 3).

Analysis of changes in performance indicators at foreign industrial enterprises resulted from introduction of controlling systems (Table 4) allows us to indicate the following positive trends in the development of these economic entities. Firstly, implementing this or that kind of controlling allowed enterprises to increase, on average, the level of investment attractiveness practically up to 9\%. Secondly, on average it allowed to increase efficiency of documents circulation practically up to $10 \%$. Thirdly, on average it allowed to increase financial stability by more than $8 \%$. 
Materials of the analytical department of the State Duma of the Russian Federation for monitoring and financial monitoring (Materials of analytical Department of the state Duma of the Russian Federation for control and financial monitoring 2004) present another official source, which provides data on implementation of the controlling system at foreign enterprises. Analysis of this source brings us to conclusion that the level of investment attractiveness resulted from implementation of the controlling system at the enterprise increases on average by $8.9 \%$, the efficiency of document circulation increases by $9.7 \%$, the level of financial stability increases by $8.3 \%$ (Table 4 ).

Table 4. Dynamics of performance indicators at foreign industrial enterprises resulted from primary implementation of controlling

\begin{tabular}{|c|c|c|c|c|}
\hline \multicolumn{2}{|c|}{ Company } & $\begin{array}{c}\text { Growth rate of the level } \\
\text { of investment }\end{array}$ & $\begin{array}{c}\text { Growth rate of workflow } \\
\text { efficiency, } \%\end{array}$ & $\begin{array}{c}\text { Growth rate of financial } \\
\text { stability, } \%\end{array}$ \\
\hline \multirow{16}{*}{ 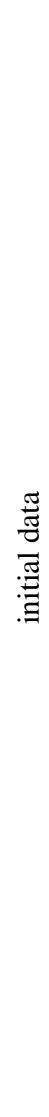 } & British Petroleum & +11.4 & +5.2 & +6.3 \\
\hline & Tesco & +9.3 & +11.6 & +8.9 \\
\hline & METRO GROUP & +7.2 & +15.3 & +22.1 \\
\hline & Cristall Gross & +6.5 & +11.3 & +22.5 \\
\hline & Ford & +1.2 & +14.8 & +6.3 \\
\hline & Mazda & +16.8 & +27.6 & +9.9 \\
\hline & Bayer AG & +3.5 & +5.2 & +2.2 \\
\hline & Schwarzkopf & +6.3 & +8.9 & +9.3 \\
\hline & Oriflame & +3.3 & +9.3 & +5.7 \\
\hline & Motorola & +6.8 & +9.3 & +11.0 \\
\hline & Chivas & +3.9 & +1.6 & +5.2 \\
\hline & Huawei & +16.5 & +11.9 & +3.5 \\
\hline & Ziegler & +0.2 & +0.96 & +0.45 \\
\hline & Singer Corporation & +1.6 & +2.9 & +3.6 \\
\hline & Renault & +13.3 & +6.9 & +9.2 \\
\hline & IBM & +33.9 & +11.8 & +6.9 \\
\hline \multirow{5}{*}{ 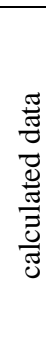 } & $\begin{array}{l}\text { Variation range for the indicator } \\
\text { value }\end{array}$ & $1.2-33.9$ & $0.96-27.6$ & $0.45-22.5$ \\
\hline & The theoretical mean value & 8.86 & 9.66 & 8.32 \\
\hline & Mean square deviation & 8.16 & 6.28 & 5.99 \\
\hline & Variability index & 92.1 & 64.99 & 72.05 \\
\hline & Integrating efficiency indicator & \multicolumn{3}{|c|}{8.93} \\
\hline
\end{tabular}

Source: compiled by the authors based on (Materials of analytical Department of the state Duma of the Russian Federation for control and financial monitoring 2004, Yunusova 2009) 


\section{ENTREPRENEURSHIP AND SUSTAINABILITY ISSUES}

ISSN 2345-0282 (online) http://jssidoi.org/jesi/

2019 Volume 7 Number 2 (December)

http://doi.org/10.9770/jesi.2019.7.2(27)

At the same time, the efficiency of the document flow is understood as an indicator calculated as the ratio of profit growth as a result of the introduction of measures improving the document flow process in the enterprise to the increase in costs due to innovation. Financial stability of the enterprise (Table 4) is determined on the basis of the coefficient of autonomy and is calculated as the ratio of the own funds of the entity to the currency of its balance sheet.

Thus, analysis of growth rates of investment attractiveness, efficiency of document circulation, financial stability of foreign industrial companies allows us to conclude that the introduction of this or that kind of controlling contributes to improving an economic situation at the enterprise and increasing its efficiency. Besides, though growth rates of indicators vary from a company to company, we observe that a general change dynamics for all analysed enterprises is positive. The resulting conclusion is that introduction of controlling systems at industrial enterprises makes it possible to increase the level of stability of the economic entity (Table 4), which is especially important in the context of recession.

At the same time, a number of researchers note the positive impact of introduction of controlling technologies on other financial, technical and economic indicators of the enterprise performance. For example, Asaul A.N., Starovoitov M.K. and Faltinsky R.A. point out in their work that the rate of increase in the sales volume due to implementation of controlling will amount to $20 \%$, net profit - to $2 \%$, and the shareholder value - to $100 \%$ (Asaul, Starovoytov, Faltinsky 2009). Moreover, the authors examine controlling in the limited framework of budgeting. Obviously, in its full capacity controlling is expected to produce even a more significant effect (Mateljak and Mihanović, 2016).

The company AT\&T Canada, the largest mobile operator in Canada, which implemented the Balanced Scorecard System (BSC), serves as another illustration of high efficiency of controlling for the enterprise. After the system was launched, the company showed the following performance dynamics: the trading profit increased by $15 \%$, the output per worker increased by $11 \%$, the market value of the enterprise showed 4 times growth. One more evidence is introduction of the controlling system at the Airbus Group, which in 2015 caused an increase in the turnover profitability by $10 \%$ (Hubert, Falco 2015).

\section{Result}

Overall, in the course of the research the author analysed increasing the efficiency of performance resulted from introduction of the controlling system at more than 70 Russian and foreign enterprises.

Giving a quantitative assessment of the impact of the controlling system introduction, it is safe to say that the introduction of the controlling system has a positive impact on the indicators of efficiency and profitability of enterprises. This means that the increase in profit as a result of improved management based on controlling exceeds the increase in the cost of these changes in the management system. Summary indicators of the analysis are presented in Table 5 .

After analyzing the results presented in table 5, it is safe to say that the introduction of the controlling system in those enterprises that have not previously used it can have a significant positive effect by increasing the overall efficiency of the enterprise. Also, during the crisis and the increased uncertainty of the external environment, the introduction of the controlling system will become a buffer reducing the negative impact on the financial and economic performance of the enterprise. 
Table 5. The impact of introduction the controlling system on performance of the enterprise

\begin{tabular}{|c|c|c|c|c|c|c|}
\hline Indicator & $\begin{array}{c}\text { The rate of } \\
\text { increase in the } \\
\text { effectiveness of } \\
\text { made decisions, } \\
\%\end{array}$ & $\begin{array}{l}\text { The rate of } \\
\text { increase in } \\
\text { managers } \\
\text { productivity, } \%\end{array}$ & $\begin{array}{c}\text { The rate of } \\
\text { increase in } \\
\text { management } \\
\text { effectiveness, } \\
\% \\
\end{array}$ & $\begin{array}{c}\text { Rate of } \\
\text { increase in the } \\
\text { quality of } \\
\text { decisions, } \%\end{array}$ & $\begin{array}{l}\text { The rate of } \\
\text { increase in } \\
\text { efficiency of } \\
\text { the production } \\
\text { process } \\
\end{array}$ & $\begin{array}{c}\text { The growth rate } \\
\text { of financial } \\
\text { stability, } \%\end{array}$ \\
\hline $\begin{array}{l}\text { Variation range for } \\
\text { the indicator value }\end{array}$ & $8.7-18.9$ & $9.6-17.2$ & $7.2-38.7$ & $18.9-43.4$ & $8.4-31.9$ & $0.45-22.5$ \\
\hline $\begin{array}{c}\text { The theoretical mean } \\
\text { value }\end{array}$ & 13.60 & 13.39 & 18.52 & 34.02 & 20.53 & 8.32 \\
\hline Mean square deviation & 2.86 & 2.48 & 9.6 & 8.61 & 5.88 & 5.99 \\
\hline Variability index & $\begin{array}{c}20.99 \\
\text { (weak } \\
\text { variation) } \\
\end{array}$ & $\begin{array}{c}18.54 \\
\text { (weak } \\
\text { variation) } \\
\end{array}$ & $\begin{array}{c}51.82 \\
\text { (moderate } \\
\text { variation) } \\
\end{array}$ & $\begin{array}{c}25.30 \\
\text { (weak } \\
\text { variation) } \\
\end{array}$ & $\begin{array}{c}28.65 \\
\text { (weak } \\
\text { variation) } \\
\end{array}$ & $\begin{array}{c}72.05 \\
\text { (strong } \\
\text { variation) } \\
\end{array}$ \\
\hline Distribution type & $\begin{array}{c}\text { normal } \\
\text { distribution }\end{array}$ & $\begin{array}{c}\text { normal } \\
\text { distribution }\end{array}$ & $\begin{array}{c}\text { normal } \\
\text { distribution }\end{array}$ & $\begin{array}{c}\text { normal } \\
\text { distribution }\end{array}$ & $\begin{array}{c}\text { normal } \\
\text { distribution }\end{array}$ & $\begin{array}{l}\text { abnormal } \\
\text { distribution }\end{array}$ \\
\hline $\begin{array}{c}\text { Confidence interval } \\
\text { for the mean } \\
\text { (significance value } \\
\alpha=0.05 \text { ) }\end{array}$ & $(11.45 ; 15.75)$ & $(11.52 ; 15.26)$ & $(13,77 ; 23,27)$ & $(22,08 ; 45,96)$ & $(16,39 ; 24,67)$ & $(5.02 ; 11.62)$ \\
\hline $\begin{array}{c}\text { Confidence interval } \\
\text { for the mean } \\
\text { (significance value } \\
\alpha=0.01 \text { ) } \\
\end{array}$ & $(10.51 ; 16.69)$ & $(10.7 ; 16.08)$ & $(12.01 ; 25.03)$ & $(14.21 ; 53.83)$ & $(14.64 ; 26.42)$ & $(5.02 ; 11.62)$ \\
\hline $\begin{array}{l}\text { Integrating efficiency } \\
\text { indicator }\end{array}$ & \multicolumn{6}{|c|}{16.42} \\
\hline
\end{tabular}

Source: own compilation

\section{Conclusions}

Having analysed the works containing a quantitative assessment of the effectiveness of implementing the controlling system at the enterprise, we found it practical to draw the following conclusions.

Introduction of controlling makes it possible to increase the effectiveness of made decisions by $8.7 \%-18.9 \%$. Moreover, it should be noted that with a probability of $95 \%$ the value of the analysed indicator falls in the range from $11.45 \%$ to $15.75 \%$. Moreover, probability of the fact that the effectiveness of the decision will the increase within the range from $10.51 \%$ to $16.69 \%$ amounts to $99 \%$. Herewith, we can also observe an increase in the productivity of managerial personnel from $9.6 \%$ to $17.2 \%$. As for this indicator, the findings are that with the probability of $95 \%$, its value falls in the range from $11.52 \%$ to $15.26 \%$, and with the probability of $99 \%$ it falls in the range from $10.7 \%$ to $16.08 \%$. The increase in management efficiency ranges from $7.2 \%$ to $38.7 \%$. Besides, we note that with the probability of $95 \%$ the value of the analysed indicator falls in the range from $13.77 \%$ to $23.27 \%$, and with the probability of $99 \%$ it falls in the range from $12.01 \%$ to $25.03 \%$. The quality level of made decisions is also growing, while the increase has a spread across the analysed enterprises from $18.9 \%$ to $43.4 \%$. For this indicator, its value falls within the range of $22.08-45.96 \%$ with the probability of $95 \%$, and with the probability of $99 \%$ it will fall in the range from $14.21 \%$ to $53.83 \%$. Introduction of the controlling system at the industrial enterprise results in an increase of the efficiency of the production process by $8.4 \%-31.9 \%$. For this 


\section{ENTREPRENEURSHIP AND SUSTAINABILITY ISSUES}

ISSN 2345-0282 (online) http://jssidoi.org/jesi/

2019 Volume 7 Number 2 (December)

http://doi.org/10.9770/jesi.2019.7.2(27)

indicator, with the probability of $95 \%$, this value falls in the range of $16.39-24.67 \%$, and with the probability of $99 \%$, it falls in the range of $14.64-26.42 \%$.

Generalization of the obtained results allows us to calculate the integrated indicator of the effectiveness of introduction of the controlling system at the industrial enterprise, which amounted to $16.42 \%$ (Table 5).

The obtained results lead to a logical conclusion that introduction of the controlling system at the enterprise is an effective method, which becomes especially relevant in the context of globalisation of economy and growth of disturbances in the external environment. The reserve, allowing to enhance business efficiency, identified when applying the controlling system, can and must act as a sort of a buffer designed to reduce negative impacts that external environment factors make on sustainability of the enterprise (Pozdnyakova et al. 2017).

Moreover, we believe that we should apply an integrated approach to launching the controlling system. It implies taking into consideration financial and economic aspects, use of certain advanced features designed to include not only functions of control, accounting and budgeting, but, in the first place, the function of preventive business management in a variable environment based on scientific simulation models. In this case, the enterprise will not only increase the effectiveness indicator of launching the controlling system, but also eliminate probability of losing financial and economic sustainability of the mini-economic system.

\section{References}

Asaul, A.N., Starovoytov, M.K. and Faltinsky, R.A. 2009. Cost management in construction: St. Petersburg.

Bertašius, D. 2007. Evaluation of the industrial enterprises management systems effectiveness [Pramonès i̧moniụ vadybos sistemu̧ efektyvumo vertinimas]. Technological and Economic Development of Economy, 13(1): 3-9.

Borgardt, E.A., Nosova, V.M. 2014. System of controlling management as management innovation of industrial organization, Vestnik VSU. Series: economy and management, 1: 108-119.

Falco, S., Russell, K. and Levin, L. 2015. Controlling in Corporate management. Retrieved from http://www.cfin.ru/management/controlling/controlling.shtml

Ghosh, B., Herzig, C., Mangena, M. 2019. Controlling for sustainability strategies: findings from research and directions for the future. Journal of Management Control, 30(1): 5-24. https://doi.org/10.1007/s00187-019-00279-8

Golovanova, N.B., Basyuk, A.S., Taranova, I.V., Kramarenko, E.R., Goloshchapova, L.V. 2016. The study of economic activity of Russian corporations in modern economy. International Journal of Economics and Financial, 6(1): 220-226.

Grynko, T., Koshevoi, M., Gviniashvili, T. 2016. Methodological approaches to evaluation the effectiveness of organisational changes at communication enterprises. Economic Annals-XXI, 156(1-2): 78-82. https://doi.org/10.21003/ea.V156-0018

Hubert, T., Falco, S.G. 2016. Financial controlling in the European aerospace and defense Group Airbus S.A.S. Controlling, 55: 3-9.

Khudyakova, T.A., Shmidt, A.V. 2018. Methodical approaches to managing the sustainability of enterprises in a variable economy. Espacios, 39(13), 28.

Mateljak, Ž., Mihanović, D. 2016. Operational planning level of development in production enterprises in the machine building industry and its impact on the effectiveness of production. Economic Research-Ekonomska Istrazivanja, 29(1): 325-342. https://doi.org/10.1080/1331677X.2016.1168041

Materials of analytical Department of the state Duma of the Russian Federation for control and financial monitoring (catalogue No. 10233.89 of December 5, 2004).

Necheukhina, N.S. 2010. The modeling of accounting events in the system of controlling in industrial enterprises: doctorate thesis, Izhevsk. 


\section{ENTREPRENEURSHIP AND SUSTAINABILITY ISSUES}

ISSN 2345-0282 (online) http://jssidoi.org/jesi/

2019 Volume 7 Number 2 (December)

http://doi.org/10.9770/jesi.2019.7.2(27)

Mousavifard, F. Ayoubi, A., Sanie, M.S. 2016. The effect of automated information system on efficiency and innovation. International Journal of Economics and Business Research, 12(2), 169-179. https://doi.org/10.1504/IJEBR.2016.079565

Parumasur, S.B., Govender, P. 2013. Role of monitoring and controlling quality in total quality management. Problems and Perspectives in Management, 11(4): 147-157.

Pelau, C., Rosca, V. 2017. Controlling instruments for the sustainability of a business: Research regarding the application of marketing controlling instruments in business. Managerial Strategies for Business Sustainability during Turbulent Times, 277-291. https://doi.org/10.4018/978-1-5225-2716-9.ch015

Pozdnyakova, U.A., Popkova, E.G., Kuzlaeva, I.M., Lisova, O.M., Saveleva, N.A. 2017. Strategic management of clustering policy during provision of sustainable development. Contributions to Economics, 1: 413-421. https://doi.org/10.1007/978-3-319-45462-7 40

Shevchuk, N. 2014. Value as a criterion for enterprise management effectiveness. Economic Annals-XXI, 5-6: 68-71.

Suhaimi, N.S.A., Nawawi, A., Salin, A.S.A.P.I. 2016. Impact of enterprise resource planning on management control system and accountants' role. International Journal of Economics and Management, 10(1): 93-108.

Syuzeva, O.V. 2010. Organisational and methodical provision of formation and development of controlling in industrial enterprises. Doctorate thesis, Moscow.

The data of the chamber of Commerce of the Russian Federation. The Bulletin Information 2006, 5.

The Pricewaterhouse Cooper's bulletin 2002, 2, London.

Vafin, L., Larionova, N. 2016. Approaches to assessing cost-effectiveness of technological innovation: The Russian industrial companies experience. Journal of Economics and Economic Education Research, 17(3): 49-55.

Yunusova, D. A. 2009. Organizational and economic mechanism of increase of economic stability of industrial enterprise (on the example of Republic Dagestan). Doctorate thesis, Makhachkala.

Yusupova, S.Y. 2008. Theory and practice of implementation of controlling system in the information society. Doctorate thesis, Moscow.

Zhuravlyov, V., Varkova, N., Aliukov, S., Khudyakova, T. 2018. Strategic aspects of ensuring sustainable development of gold enterprises of the Russian Federation. Sustainability, 10(12), 4410. https://doi.org/10.3390/su10124410

\section{Aknowledgements}

South Ural State University is grateful for financial support of the Ministry of Education and Science of the Russian Federation (grant No 26.9677.2017/BP). The work was supported by Act 211 Government of the Russian Federation, contract № 02.A03.21.0011. 


\section{ENTREPRENEURSHIP AND SUSTAINABILITY ISSUES}

ISSN 2345-0282 (online) http://jssidoi.org/jesi/

2019 Volume 7 Number 2 (December)

http://doi.org/10.9770/jesi.2019.7.2(27)

Tatyana KHUDYAKOVA is Doctor of Science (Economics) and the Head of the Department "Applied Economics" South Ural State University (National Research University), Russia. Research interests: entrepreneurship and regional development; innovation and small firms; small firm internationalization; sustainability. Scopus ID 57190005672.

ORCID ID: https://orcid.org/0000-0001-5397-0498

Andrey SHMIDT is Doctor of Science (Economics) and the Professor of the Department "Applied Economics" South Ural State University (National Research University) and prorector, Russia. Research interests: entrepreneurship and regional development; innovation and small firms; small firm internationalization; sustainability. Scopus ID 56712529300.

ORCID ID: $\underline{\text { https://orcid.org/0000-0003-3575-6898 }}$

Svetlana SHMIDT is undergraduate student of the Department "Mathematics and Computer Science" Saint-Petersburg State University, Russia. Research interests: application of mathematical methods in applied research and computer science.

ORCID ID: https://orcid.org/0000-0002-8967-0611

Copyright (C) 2019 by author(s) and VsI Entrepreneurship and Sustainability Center

This work is licensed under the Creative Commons Attribution International License (CC BY).

http://creativecommons.org/licenses/by/4.0/

cC) (†) Open Access 